\title{
EQUAL PRICE TREATMENT UNDER THE ROBINSON-PATMAN ACT
}

\author{
By P. J. B. Crowley $†$
}

When the Robinson-Patman Act became a law approximately ten years ago, ${ }^{1}$ questions arose concerning both its constitutionality and its practical workability, due to the absence therefrom of specific guides of prohibited and permissible action. The constitutionality of the Act has long since been decided. ${ }^{2}$ Many practical difficulties in applying the Act to specific situations still exist, however, despite the many guides for action now educible from the decisions of the courts. This fact received recent judicial recognition in the comment of Judge Lindley in United States v. New York Great Atlantic \& Pacific Tea Co. ${ }^{3}$

"I doubt if any judge would assert that he knows exactly what does or does not amount to violation of the Robinson-Patman Act in any and all instances."

Apparently, the Supreme Court has been mindful of this fact having already given consideration to two cases arising under the Act ${ }^{4}$ and, more recently, having consented to hear an additional case ${ }^{5}$ while denying certiorari in three cases which presented no outstanding points of novel interest. ${ }^{6}$

$\dagger$ B. A., I9II, LL.B., I935, Fordham University, General Motors Corporation, Member of the Detroit Bar.

I. The Robinson-Patman Act, 49 STAT. I526-I528 (I936), I5 U. S. C. §§ I3, I3a, I3b, 2Ia (I940), became law June I9, I936, although 52 STAT. 446 (1938), I5 U. S.' C. $\S$ I3c, exempting non-profit institutions became a law May 26,1938 .

2. The basic justification for the Act on constitutional grounds advanced by the Congressional proponents thereof was Sugar Institute v. United States, 297 U. S. 553, 597 (1936), affirming United States v. Sugar Institute, I5 F. Supp. 817 (1934), in which the Supreme Court indicated that discriminations in price between the customers of the type subsequently covered by the Robinson-Patman Act might well be prohibited by Congress under its interstate commerce powers.-80 CoNG. REC. 8223 (I936).

3. 67 F. Supp. 626, 677 (E. D. I11. I946).

4. Corn Products Refining Co. v. Federal Trade Commission, 324 U. S. 726 (I945); Staley Manufacturing Co. v. Federal Trade Commission, 324 U. S. 746 (I945).

5. In Bruce's Juices v. American Can Co., 155 Fla. 877, 22 S. (2d) 46r (I945) the Florida Supreme Court held in an action on a promissory note for a cancelled purchase by defendant that the defense that the sale constituted a violation of the Robinson-Patman Act was not available under the evidence. Petition for certiorari was filed September 5, 1945, and cert. granted November I3, I945, 326 U. S. 7II, affirmed. by an equally divided court February II, I946, $327 \mathrm{U}$. S. 758 , rehearing granted, case restored to docket for reargument before full bench and motion to withhold issuance of mandate granted March, I946, 327 U. S. 812.

6. Southgate Brokerage Co. v. Federal Trade Comm., r5o F. (2d) 607 (C. C. A. 4th, 1945), cert. denied, 326 U. S. 774 (I945); Elizabeth Arden Sales Corp. v. Gus 
It is timely, therefore, to consider some of the practical questions which not uncommonly arise under the Act, more specifically, certain significant phases of Section 2 (a) through (f) ${ }^{7}$ on given pricing practices.

While the court in the recent $A \& P$ case expressed doubt that there ever was any need for the addition of the Robinson-Patman Act to existing anti-trust statutes, ${ }^{8}$ the Act was designed to make more effective the previously existing restrictions against price discriminations. This end was sought by more precisely reframing Section 2 of the Clayton Act so as to limit quantity discounts and protect competitors individually as well as competition generally ${ }^{\text {sa }}$ (Section 2 (a)), by imposing the burden of justification on the person violating

Blass Co., I50 F. (2d) 988 (C. C. A. 8th, I945), cert. denied, 326 U. S. 773 (I945); Samuel H. Moss, Inc. v. Federal Trade Comm., I48 F. (2d) 378 (C. C. A. 2d, 1945), cert. denied, 326 U. S. 734 (I945), rehearing denied, 326 U. S. 809 (I945).

7. No proceeding has as yet been undertaken under Section 3 of the Act, the socalled "Borah-Van Nuys Act," which was enacted with and as a part of the Robinson-Patman Act [49 STAT. I528 (I936), I5 U. S. C. \& I3a (I940)], which is a criminal statute. In the recent $A$. \& $P$. prosecution, cited supra note 3 , that company's conviction of price discrimination was under the Sherman Act, although proceedings might also have been taken under the Robinson-Patman Act.

8. The court said in the recent $A$. \& $P$. case, United States v. New York Great Atlantic \& Pacific Tea Co., 67 F. Supp. 626, 676 (E. D. Ill. 1946).

"Sometimes I doubt whether we ever needed the Robinson-Patman law, with all its elusive uncertainty. I have thought that the Sherman Act, properly interpreted and administered, would have remedied all the ills meant to be cured. . . ."

8a. Section 2 (a) of the Act, 49 STAT. I526 (1936), I5 U. S. C. § I3 (a) (1940), reads as follows:

"(a) That it shall be unlawful for any person engaged in commerce, in the course of such commerce, either directly or indirectly, to discriminate in price between different purchasers of commodities of like grade and quality, where either or any of the purchases involved in such discrimination are in commerce, where such commodities are sold for use, consumption, or resale within the United States or any Territory thereof or the District of Columbia or any insular possession or other place under the jurisdiction of the United States, and where the effect of such discrimination may be substantially to lessen competition or tend to create a monopoly in any line of commerce, or to injure, destroy, or prevent competition with any person who either grants or knowingly receives the benefit of such discrimination, or with customers of either of them: Provided, That nothing herein contained shall prevent differentials which make only due allowance for differences in the cost of manufacture, sale, or delivery resulting from the differing methods or quantities in which such commodities are to such purchasers sold or delivered: Provided, however, That the Federal Trade Commission may, after due investigation and hearing to all interested parties, fix and establish quantity limits, and revise the same as it finds necessary, as to particular commodities or classes of commodities, where it finds that available purchasers in greater quantities are so few as to render differentials on account thereof unjustly discriminatory or promotive of monopoly in any line of commerce; and the foregoing shall then not be construed to permit differentials based on differences in quantities greater than those so fixed and established: And provided further, That nothing herein contained shall prevent persons engaged in selling goods, wares or merchandise in commerce from selecting their own customers in bona fide transactions and not in restraint of trade: And provided further, That nothing herein contained shall prevent price changes from time to time where in response to changing conditions affecting the market for or the marketability' of the goods concerned, such as but not limited to actual or imminent deterioration of perishable goods, obsolescence of seasonal goods, distress sales under court process, or sales in good faith in discontinuance of business in the goods concerned." 
the Act (Section 2 (b)), ${ }^{9}$ by making receipt of price discriminations unlawful (Section 2 (f)), ${ }^{10}$ and by specifically forbidding three trade practices which were deemed inevitably injurious to competition: the granting of a fictitious brokerage fee or any allowance in lieu thereof to the other party to the transaction or his agent (Section 2 (c)), ${ }^{11}$ the making of discriminatory payments by the seller to the buyer for services rendered by the latter (Section 2 (d)), ${ }^{12}$ and discrimination by the seller in the rendering of services to the buyer (Section 2 (e)).$^{13}$

Quite pragmatically, the first concern of the businessman is the sanction or sanctions attaching to a failure to abide by the provisions

9. Section 2 (b) of the Act, 49 STat. I526 (I936), I5 U. S. C. § 13 (b) (1940), reads as follows:

"Upon proof being made, at any hearing on a complaint under this section, that there has been discrimination in price or services or facilities furnished, the burden of rebutting the prima-facie case thus made by showing justification shall be upon the person charged with a violation of this section, and unless justification shall be affirmatively shown, the Commission is authorized to issue an order terminating the discrimination: Provided, however, that nothing contained in sections I2, I3, I4-21, 22-27 of this title shall prevent a seller rebutting the primafacie case thus made by showing that his lower price or the furnishing of services or facilities to any purchaser or purchasers was made in good faith to meet an equally low price of a competitor, or the services or facilities furnished by a competitor."

10. Section 2 (f) of the Act, 49 STAт. I527 (r936), I5 U. S. C. $\$$ I3 (f) (I940), reads as follows:

"That it shall be unlawful for any person engaged in commerce, in the course of such commerce, knowingly to induce or receive a discrimination in price which is prohibited by this section."

II. Section 2 (c) of the Act, 49 STAT. I527 (I936), 15 U. S. C. § I3 (c) (1940), reads as follows:

"That it shall be unlawful for any person engaged in commerce, in the course of such commerce, to pay or grant, or to receive or accept, anything of value as a commission, brokerage or other compensation, or any allowance or discount in lieu thereof, except for services rendered in connection with the sale or purchase of goods, wares, or merchandise, either to the other party to such transaction or to an agent, representative, or other intermediary therein where such intermediary is acting in fact for or in behalf, or is subject to the direct or indirect control, of any party to such transaction other than the person by whom such compensation is so granted or paid."

I2. Section 2 (d) of the Act, 49 STAT. I527 (I936), I5 U. S. C. § I3 (d) (I940) reads as follows:

"That it shall be unlawful for any person engaged in commerce.to pay or contract for the payment of anything of value to or for the benefit of a customer of such person in the course of such commerce as compensation or in consideration for any services or facilities furnished by or through such customer in connection with the processing, handling, sale, or offering for sale of any products or commodities manufactured, sold, or offered for sale by such person, unless such payment or consideration is available on proportionally equal terms to all other customers competing in the distribution of such products or commodities."

I3. Section 2 (e) of the Act, 49 STAт. I527 (1936), I5 U. S. C. \$ I3 (e) (I940), reads as follows :

"That it shall be unlawful for any person to discriminate in favor of one purchaser against another purchaser or purchasers of a commodity bought for resale, with or without processing, by contracting to furnish or furnishing, or by contributing to the furnishing of, any services or facilities connected with the processing, handling, sale, or offering for sale of such commodity so purchased upon terms not accorded to all purchasers on proportionally equal terms." See Oliver Bros. v. Federal Trade Commission, 102 F. (2d) 763,767 (C. C. A. 4th. 'r939). 
of the Robinson-Patman Act. Not only are there the penalties provided by the Act itself but, as the court pointed out in the $A \& P$ case, the penalties of the Sherman Act may also be brought to bear upon one violating the Act, namely, a $\$ 5,000$ fine or imprisonment for one year or both. ${ }^{14}$ The Robinson-Patman Act itself also provides (in Section 3 ) for a penalty of a $\$ 5,000$ fine or, in the alternative, one year's imprisonment, ${ }^{15}$ although no action has as yet been taken under this section. In addition, however, there are four other types of effect which the Act may have upon the businessman who violates its provisions: The Federal Trade Commission may proceed against the party violating the Act; ${ }^{10}$ the injured party may institute action against the discriminating seller for triple damages; ${ }^{17}$ the injured party or the local U. S. District Attorney under the direction of the AttorneyGeneral may obtain injunctive relief ${ }^{18}$-and it is important to note that an officer or agent of the seller is equally liable with the seller; ${ }^{18}$ or the person involved in a discriminatory contract may seek to avoid the contract. ${ }^{20}$ The last of these sanctions may require a word of explanation.

It may be that a seller and purchaser will enter into a contract which quotes prices which are in fact (rather than expressly by the contract) discriminatory as compared with the prices given by the seller to his other customers. Such a contract is not invalid per se, but is merely collateral to a practice prohibited by the statute. Conse-

14. 26 Stat. 209 (I890), I5 U. S. C. \$ I (I940). In the $A$. \& $P$. case, the defendants were prosecuted and convicted only under the Sherman Act. No charges were brought directly under the provisions of the Robinson-Patman Act.

15. Any individual, whether acting in his own right or as a representative of a corporation, who is a party to a transaction or contract which is in violation of Section 3 of the Robinson-Patman Act is legally liable therefor by reason of Section 14 of the Clayton Act, 38 STAT. 736 (I914), I5 U. S. C. \$ 24 (I940).

16. 3 S STAT. 734 (I9I4), I5 U.'S. C. \$2I (I940): "Authority to enforce compliance with sections 13 . of this title by the persons respectively subject thereto is hereby vested .. in the Federal Trade Commission. . .

I7. 38 STAT. 73I (I9I4), I5 U. S. C. \$I5 (I940), gives the injured party a right to an action for triple damages as follows:

"That any person who shall be injured in his business or property by reason of anything forbidden in the anti-trust laws may sue therefor in any district court of the United States in the district in which the defendant resides or is found or has an agent, without respect to the amount in controversy, and shall recover threefold the damages by him sustained, and the cost of suit, including a reasonable attorney's fee."

I8. 38 Stat. 737 (I9I4), I5 U. S. C. $\$ 26$ (I940).

I9. See Kentucky-Tennessee Light \& Power Co. v. Nashville Coal Co., 37 F. Supp. 728 (W. D. Ky. I94I), a'ffd. 136 F. (2d) I2 (C. C. A. 6th, 1943). A power company sued Fitch, its former president, for accepting and defendant company and Potter, an officer of defendant company, for paying commissions to such president on coal purchased by the Power Company from defendant.

20. The essential reason for avoiding the contract would be that there is no legal consideration therefor or that an illegal consideration is an essential part of the whole consideration. Bruce's Juices v. American Can Co., I55 Fla. 877, 22 S. (2d) 46r (I945); Gross Bros. Flour Co. v. International Milling Co., C. C. H. Trade Reg. Serv. (9th ed.) $\pi 57,262$ (S. D. N. Y. 1944). 
quently, it is enforceable either in a suit by the seller for the payment of drafts accepted by the purchaser covering the commodities sold or in an action for the balance of the purchase price. ${ }^{21}$

On the other hand, a seller and a purchaser may be parties to a contract which provides for an act violative per se of the RobinsonPatman Act, for example, a contract providing for payment of unlawful rebates. ${ }^{22}$ Such a contract is absolutely void and unenforceable and the valid provisions thereof cannot be considered as severable from the illegal provision for rebates, since the latter provision would constitute an essential part of the consideration and the contract in its severed state would therefore, lack mutuality. ${ }^{23}$ In such a case, nevertheless, a seller could evidently recover for goods already sold and delivered on a quantum valebat basis. $^{24}$

If, however, the contract between the seller and purchaser provided solely for the payment of a fee by the seller to a broker acting for the purchaser, the contract would not only be void and unenforceable as to future services, but no recovery would be permissible even on a quantum meruit basis for past services supplied thereunder. ${ }^{25}$ This would be true, even though the broker might have performed substantial services for the seller, since the primary and essential services furnished by the broker would have been performed for the purchaser whose position is of its very nature adverse to that of the seller so that no legal consideration for a brokerage fee could possibly be given by the broker to the seller. The interdiction of Section 2 (c) renders payment of a brokerage fee under the circumstances illegal per se and absolutely void as against public policy. ${ }^{20}$

Turning from the sanctions attaching to violations of the Act to the substantive provisions of the Act, it will undoubtedly be found most convenient to consider Section 2 (a) first and then, in turn, Sections 2 (c), (d) and (e).

An analysis of Section 2 (a) shows that five elements must be present in an act which violates the provisions of the section. There must be a sale of a commodity in interstate or foreign commerce for use or resale in the United States. There must be two or more purchasers from the same seller. The commodity involved in the sales

2I. Bruce's Juice v. American Can Co., I55 Fla. 877, 22 S. (2d) 46I (I945), cited supra note 5; cf. Gross Bros. Flour Co. v. International Milling Co., C. C. H. Trade Reg. Serv. (gth ed.) $\int 57,262$ (S. D. N. Y. I944).

- 22. Jarrett v. Pittsburgh Plate Glass Co., I3I F. (2d) 674 (C. C. A. 5th, 1942).

23. Id. at 676 . (1922).

24. Penn-Allen Cement Co. v. Phillips \& Sutherland, I82 N. C. 437, I09 S. E. 257

25. Quality Bakers of America v. Federal Trade Comm., II4 F. (2d) 398 (C. $\dot{C}$.

A. Ist, I940).

26. See discussion of Section 2 (c), infra, page $\overline{3} 33$. 
to the two purchasers must be of like grade and quality. There must be a discrimination in the price of such commodity as between the two purchasers. There must be probability of injury to competition or to a competitor.

In connection with the commerce requirement, the important question arises: Does the Act cover a discriminatory sale which takes place wholly within a state? This is a problem of vital interest to the local businessman and also to the large corporation doing both an interstate and intrastate business.

The commerce requirement of Section 2 (a) of the Robinson-Patman Act is as follows:

“. . . it shall be unlawful for any person engaged in commerce, in the course of such commerce, either directly or indirectly, to discriminate in price between different purchasers of commodities of like grade and quality, where either or any of the purchases involved in such discrimination are in commerce, where such commodities are sold for use, consumption, or resale within the United States or any Territory thereof or the District of Columbia or any insular possession or other place under the jurisdiction of the United States . . ."

It will be observed, therefore, that first the seller must be engaged in commerce, that is, in interstate or foreign commerce on the basis of the applicable definition of "commerce" set forth in the Clayton Act. ${ }^{27}$ In addition, there must be a discrimination by the seller which involves a sale of a commodity in interstate or foreign commerce.

From these concepts it follows that an injured purchaser or seller need not be in interstate commerce in order to have rights against another seller who discriminates with respect to sales made by such other seller in interstate commerce. This was made manifest in Midland Oil Co. v. Sinclair Refining $\mathrm{Co}_{0}{ }^{28}$ There, the plaintiff suing for treble damages was an Illinois corporation buying gasoline from another Illinois corporation and distributing the same to its customers in the City of Chicago. The plaintiff had no contractual relations whatsoever with the defendant, which distributed gasoline in interstate commerce at discriminatory prices to one of plaintiff's purchasers. The court held that the plaintiff had a cause of action. The test applied was simply this: If a seller is engaged in interstate commerce and discriminates between two of his purchasers, thereby damaging another seller, the latter has a cause of action under the Act. If this test is applied, then

27. Section I of the Clayton Act, 38 STAT. 730 (I9I4), I5 U. S. C. $\$$ I2 (I940). 28. 4I F. Supp. 436 (N. D. III. I94I). 
apparently the same conclusion would likewise follow even if a discriminatory sale made by a seller generally engaged in selling in interstate commerce were to originate and be consummated wholly within one state. For the Act does not require that both sales by a discriminating seller be in commerce, but only that "either or any of the purchases involved" be in commerce. In contrast, however, a seller who is engaged wholly in intrastate commerce is immune from the Act as respects discriminatory intrastate sales since the seller is not "engaged in commerce" within the meaning of the Act.

Even if the seller is engaged in interstate or foreign commerce and makes a discriminatory sale in such commerce, the sale may nevertheless be outside the coverage of the Act if the item sold is not sold for use, consumption, or resale within the United States. Sales, for example, by a company located in the United States to foreign purchasers are immune from the Act since the commodities so sold are not for use in the United States. ${ }^{29}$ Yet purchases by such a company from foreign sellers are subject to the Act if the commodities purchased are to be used, consumed or resold within the United States. ${ }^{30}$ Obviously, only where the commodity sold is to be used, consumed or resold in the United States would a discrimination have an adverse effect on the domestic competitive situation which Congress desired to safeguard.

With respect to the second stated requisite for a violation of Section 2 (a), that there be two purchasers from the same seller, the statute says that "it shall be unlawful for any person . . . to discriminate in price between different purchasers. . . ." It is on the basis of this language that it is concluded that the two purchasers must buy from the same person since only the one person (i. e., a discriminating seller) is mentioned in the section and the words "two purchasers" which are necessarily correlative in that they imply a seller, could not, therefore, grammatically, relate back to any person other than the discriminating seller.

In the recent case of Elizabeth Arden, Inc. v. Federal Trade Commission, ${ }^{31}$ the point was referred to obliquely. The petitioners expressed an apprehension that the Federal Trade Commission order issued against them in respect of Section 2 (e) might compel them to accord demonstrator services on proportionally equal terms to retail stores which acquired Arden products from so-called bootlegging sources, thus raising the question whether the word "purchasers" in

29. 8o CoNG. ReC. 6582 (1936).

30. United States v. N. Y. Amsterdamsche Chininefabrick, consent decree (S. D. N. Y., Sept. I928), 3 C. C. H. Fed. Trade Reg. Serv. II 33I7 (I928) (applying the earlier section 2 of the Clayton Act).

3I. I56 F. (2d) I32 (C. C. A. 2d, 1946). 
Section 2 (e) might not be broad enough to include any purchasers of the commodity involved, rather than only direct purchasers from a discriminating seller. As the question was held not to have arisen in the proceedings before the Commission, the court construed the Federal Trade Commission order as not intended to cover allowances to such indirect purchasers, but specifically stated, by way of footnote, that the court did not consider the question whether persons buying from "bootleggers" are "purchasers" within the meaning of subsection 2 (e) of the Act. It may be observed, in any event, that the words "purchaser" and "purchasers" as used in Section 2 (e) are somewhat different in context and might have been intended to convey a broader meaning than the use of the word "purchasers" in Section 2 (a)..$^{32}$

With regard to the requirement that there must be two purchasers from the same seller, two significant questions arise: Can a seller or buyer avoid the Act by reason of the separate corporate identity of its various operations? Can a seller avoid the Act by selling to one purchaser at a given price and by refusing to sell to a competitive customer except at a discriminatory price?

The first inquiry arises chiefly in the case of a large enterprise doing business through various corporate subsidiaries. A large enterprise, for example, in order to achieve most efficient distribution may be in the position of distributing different lines of its products through different subsidiaries and yet each line may include many identical items. Each of the subsidiaries may sell its respective line at different prices to its own set of purchasers who, in turn, however, may, in some instances, be in substantial competition with purchasers from the other subsidiary. Perhaps it is unsound business practice for two subsidiaries of the same corporation thus to sell an identical item at two different prices; nevertheless, the situation, it will be found, probably is the result of the differing impact of competitive forces upon each of the subsidiary corporations. Will the separate corporate identity of each of the subsidiaries protect them and their parent corporation in the circumstances from a charge of selling to competitive customers of the subsidiaries at different prices?

If the customers have the practical opportunity to buy from either subsidiary, there is, of course, no problem, since there is then no discrimination. The problem exists only if one set of customers are per-

32. Section 2 (e), 49 Stat. I527 (I936), I5 U. S. C. $\$$ I3 (e) (I940), provides in this respect that:

"That it shall be unlawful for any person to discriminate in favor of one purchaser against another purchaser or purchasers of a commodity bought for resale : - by contracting to furnish or furnishing, or by contributing to the furnishing of, any services or facilities . . . upon terms not accorded to all purchasers on proportionally equal terms." 
mitted to buy only from one subsidiary and at a higher price than that which is available to customers of the other subsidiary.

From the decisions of the Federal Trade Commission, it would appear that purchasers from various of the wholly owned subsidiaries of a corporation will be treated as purchasers from one and the same seller. $^{33}$. This is probably due to the presumed existence of a common purpose, policy and control with respect to the wholly owned subsidiaries of a corporation akin to that which exists with respect to the operating divisions of a corporation. If this reasoning is adopted, it may be deduced therefrom that the Federal Trade Commission will go beyond legal identity and look at the competitive identity of interest.

The point under consideration was neither specifically remarked upon nor decided in the cited cases, however, and it is suggested that the sounder reasoning under the language of the Act, would save the subsidiary companies and their parent corporation from a charge of price discrimination on the basis of the facts proposed; since the competitive customers of each subsidiary are not in fact buying from the same seller, i. e., the same legal entity, which in legal contemplation must be the accepted meaning of the words "the same seller," particularly in view of the wording of the statute as previously considered. It can by no means be concluded, however, that this is the reasoning that would prevail, particularly in view of the consideration given in the $A \& P$ case to the corporate device adopted by one of A \& P's suppliers at A \& P's behest to escape the impact of Section 2 (c) of the RobinsonPatman Act forbidding fictitious brokerage fees. ${ }^{34}$

The court did not state whether this practice on the part of the United States Products Corporation was illegal per se. Neither did the court find that the A \& $\mathrm{P}$ was guilty of restraining trade merely because the $\mathrm{A} \& \mathrm{P}$ made the United States Products Corporation set up a separate corporation for brokerage sales so that it might have the benefit of cost savings from the United States Products Corporation doing business exclusively as a direct seller.

In the event, however, that the separate incorporation of an enterprise's activities, whether engaged in selling or buying; constitutes part of a system or combination in restraint of trade, it will, of course, as in the $A \& P$ case, come within the interdiction of the Sherman anti-trust law.

If it is arguable whether two separate corporations, affiliated through ownership by the same parent corporation, may sell the same

33. Caradine Hat Co., 39 F. T. C. 515I (I944); Sherwin-Williams Co. 36 F. T. C. 25 (I943); U. S. Rubber Co., 28 F. T. C. 1489 (1939).

34. Cited supra note 3 , at 644 . 
commodity at different prices to competitive customers, it is, in contrast, quite clear that a seller may sell to its wholly owned subsidiaries at no better prices than are offered to its independent purchasers. ${ }^{35} \mathrm{~A}$ manufacturer may, of course, give preferences to its own retail outlets which are not separately incorporated since then there is no "sale" of any kind. ${ }^{36}$

The corporate aspect presents two other situations of interest under the Act. A seller may sell at different prices to the same purchaser, whether in the same or different section of the country unless, of course, there is a purpose to destroy competition or a competitor or unless another purchaser is involved. ${ }^{37}$ Likewise, a seller will probably be permitted to sell to two subsidiary corporations, $A$ and $B$, wholly owned by another corporation $C$, where $A$ and $B$ are located in two different cities. A price difference in each of the factual situations described would be permissible since, in the first case, no discrimination between different purchasers would be involved and, in the second case, no injurious effect on competition would ordinarily result.

The second inquiry mentioned with respect to the requirement that two purchasers must be involved in an act violative of Section 2 (a) was considered by the court in Shaw's, Inc. $v$. Wilson-Jones Co. ${ }^{38}$ The plaintiff had sued the defendant for treble damages because the defendant, sole manufacturer of election supplies, refused to sell to the plaintiff with whom it had formerly dealt, although it had previously indicated that it would do so; instead, the defendant sold solely to a competitor of the plaintiff. The court dismissed the complaint.

On the other hand, inasmuch as the gravamen of the offense is the probable adverse effect on competition, ${ }^{39}$ logically the illegal act would seem to be complete as soon as one sale was consummated and an offer to sell at a discriminatory price was made by the seller to a prospective buyer, even though a second sale was not consummated. ${ }^{40}$

35. Sherwin-Williams Co., 36 F. T. C. 25 (I943).

36. Jarrett v. Pittsburgh Plate Glass Co., I3I F. (2d) 674 (C. C. A. 5th, 1942).

37. Even if the excepted practice in question were not in violation of Section 2 (a), it would be clearly contrary to the provisions of Section 3 of the Act, wherein it is provided that "It shall be unlawful for any person, engaged in commerce, in the course of such commerce . . . to sell or contract to sell goods in any part of the United States at prices lower than those exacted by said person elsewhere in the United States for the purpose of destroying competition, or eliminating a competitor in such part of the United States; or, to sell, or contract to sell, goods at unreasonably low prices for the purpose of destroying competition or eliminating a competitor."

38. 105 F. (2d) 33I (C. C. A. 3d, I939).

39. Corn Products Refining Co. v. Federal Trade Comm., 324 U. S. 726 (I945).

40. Such an inference may be drawn from the Shaws' case, cited note 38 supra, where the court said at page 334 of its opinion:

"Since no goods or commodities were offered to the appellant, the terms of the subsection are not met." (Italics ours.) 
And although a seller has full liberty to choose his customers, this liberty is not an unrestricted freedom and can be exercised only "in bona fide transactions and not in restraint of trade." 41

The third element necessary for a violation of Section 2 (a), as previously analyzed, is that the commodities involved in different sales be of "like grade and quality." What, then, are "commodities" arid to what extent does this word cut down the applicability of the Section?

In the classic legal sense, the term "commodities in commerce" has always included only things such as merchandise and not services such as insurance ${ }^{42}$ or, apparently by the same token, financing. ${ }^{43}$ Despite both this limitation of the word "commodity," and the fact that the Robinson-Patman Act applies only to price discriminations in regard to "commodities of like grade and quality" the Act probably would be held to apply to services used in or in connection with interstate commerce. Hence, discriminatory prices in insurance, financing, or any similar service might be subject to the Act. The price of the services could be tied in with the related commodities, so as to make the latter the "commodities" in respect of which the discrimination is effected in order to satisfy the requirement of the Act; ${ }^{44}$ or the service itself, because of its inextricable tie-in with commodities in interstate commerce could itself be deemed an integral part of such commodities. ${ }^{45}$

Directing attention, however, to the term "commodities" in its more usual sense, an analysis of the cases and of the Federal Trade Commission decisions supports the description of "commodities of like grade and quality" as commodities designed for the same end purpose and substantially the same (although superficially different) in design, constituents and construction. This is in keeping with the language of the statute which was calculated to embrace evasive practices obtaining with respect to the manufacture and sale to different purchasers

4I. Quality Bakers of America v. Federal Trade Comm., II4 F. (2d) 393 (C. C. A. Ist, 1940); Webb-Crawford Co. v. Federal Trade Comm., Iog F. (2d) 268 (C. C. A. 5th, 1940); Great Atlantic and Pacific Tea Co. v. Federal Trade Comm., Io6 F. (2d) 667 (C. C. A. 3d, I939), cert. denied, 308 U. S. 625 (1939), rehearing denied, 309 U. S. 694 (1940) ; Oliver Bros. v. Federal Trade Comm., ro2 F. (2d) 763 (C. C. A. 4th, I939) ; Biddle Purchasing Co.v. Federal Trade Comm., 96 F. (2d) 687 (C. C. A. 2d, I938), cert. denied, 305 U. S. 634 (I938).

42. Stone, C. J., dissenting in South-Eastern Underwriters Association, 322 U. S. 533, 570-574 (r944).

43. Cf., however, United States v. General Motors Corporation, I2r F. (2d) 376 (C. C. A. 7 th, I94I), cert. denied, $3 \mathrm{I} 4$ U. S. 6I8, rehearing denied, $3 \mathrm{I} 4$ U. S. 710 , and General Motors Corporation et al. v. Federal Trade Comm., II4 F. (2d) 33, 36 (C. C. A. 2 d, I940), cert. denied, 312 U. S. 682.

44. United States v. General Motors Corporation, I2I F. (2d) 376 (C. C. A. 7th, I94I). Where the Sherman Act rather than the Robinson-Patman Act was involved, but the point above made is equally applicable.

45. Black, J., writing for the 4-3 majority in South-Eastern Underwriters, 322 U. S. 533 (1944). 
under different special brand names of substantially the same commodity. ${ }^{46}$

An important and interesting exception to the foregoing definition occurs, however, where a commodity, which is of like grade and quality to another commodity, is sold in combination with a third commodity. There the combination has been held to change the grade and quality of the first commodity in relation to the second. In Package Closure v. Sealright the complaint alleged that the defendant sold milk bottle cap-and-hood combinations at unreasonably low prices, thus discriminating between customers who bought hoods from the defendant and those who bought hoods from the plaintiff, which did not sell caps. The Court of Appeals for the second circuit held that such a complaint did not allege a price discrimination in violation of the Robinson-Patman Amendment to the Clayton Act. ${ }^{47}$

The Package Closure holding in this respect does not seem logical or sound law, however, since first, as Frank, J., pointed out by way of dissent : 48

“. . . there were sales of caps to those who purchased them in combination with hoods at prices which discriminated against those who purchased caps only. In both instances, the same product, caps, were actually sold."

And second, it is illegal under Section 3 of the Clayton Act, the tying-in prohibition, to sell an item to a customer on condition that he must buy another in combination therewith or to extend to him special terms in consideration of his buying a second such item. ${ }^{49}$

What practical guides, then, it may be inquired, are there for determining whether or not two articles are of "like grade"?

The question is particularly pertinent in view of the fact that a manufacturer, by reason of the very definition of "grade," may in good faith consider two similar articles, even of approximately the same

46. U. S. Rubber Co., 28 F. T. C. 1489 (1939). See Bagley, Four Years Under the Robinson-Patman Act (I94I) 25 MINN. L. REv. I3I. 2d, 1944).

47. Package Closure Corp. v. Sealright Co., I4I F. (2d). 972, 979-980 (C. C. A.

48. Id. at 980 .

49. Section 3 of the Clayton Act, 38 Stat. 73I (I9I4), I5. U. S. C. \$ I4 (I940), provides :

“. . . It shall be unlawful for any person engaged in commerce, in the course of such commerce, to lease or make a sale or contract for sale of goods . . . for use, consumption, or resale within the United States . . . or fix a price charged therefor, or discount from, or rebate upon, such price, on the condition . . . that the lessee or purchaser thereof shall not use or deal in the goods.. - of a competitor or competitors of the lessor or seller, where the effect of such lease, sale or contract for sale or such condition, agreement, or understanding may be to substantially lessen competition or tend to create a monopoly in any line of commerce." 
quality, to be of different grades and charge different prices therefor. "Grade" is defined by Webster as "a class constituted by things having the same relative position or standing. . . ." It follows that two similar articles, even when they are of approximately the same quality, may not have the same relative position or standing in the eyes of the buying public so that as a result one article might have a better extrinsic value than another and, therefore, command a better price. For example, if a manufacturer makes two products of the same type and quality and attaches his own trade name or a warranty to one so that by reason thereof it commands a better price than the-other, it may be assumed that the manufacturer has acted in good faith in placing the selected product in a higher grade and establishing a higher price therefor. Where advertising or warranty service has added to the connotation of reliability of the selected product, an element of cost justification for the different prices of the two grades will also exist.

It must be recognized, of course, that whether all merchandise of the same kind and of substantially the same quality is of the same grade is a question of fact. It has been held, for example, that two -commodities of substantially the same constituents and performing the same end purpose, but bearing different private brand names, are of "like grade and quality" within the comprehension of the RobinsonPatman Act. ${ }^{50}$ The position that two commodities are not of the same grade can be more easily supported, therefore, accordingly as the differences in constituents and construction are greater. No rule of thumb can be laid down in the latter respect.

From what has been said, it likewise follows that all customers of a particular seller who buy private brand merchandise of the same grade and quality, that is, merchandise which is substantially the same in constituents, construction and end purpose, must be given the same prices, discounts, and allowances in respect of such merchandise, even though the merchandise sold to each customer bears a different brand name or no name at all. ${ }^{51}$

The fourth element involved in an act violative of Section 2 (a) is the element of price discrimination, and in this respect the Act prohibits direct as well as indirect price discriminations.

50. United States v. Rubber Co., 28 F. T. C. I489 (I939).

5I. See remarks of Mr. Teegarden in his opinion of the House Hearings on the Act, Hearings Before Committee on Judiciary on $H . R$. 8442, 74th Cong., 2d Sess. (I936) 469 :

"Under the Patman bill as it stands, manufacturers are still free to put up their products under private brands; but if they do so for one purchaser under his private brand, then they must be ready to do so on the same terms, relative to their comparative costs, for a competing purchaser under his private brand; and unless that equality of treatment is required and assured, the discriminations at which the bill is aimed cannot be suppressed." 
The term "discrimination in price, direct or indirect" has been held applicable not only in the case of simple, direct price discriminations, as where a seller charges one purchaser $\$ 5$ for a commodity and another purchaser \$Io for the same commodity, but also to such indirect discriminations as freight, discrimination in the terms of sale or other allowances, ${ }^{52}$ or the privilege of returning unsold items. ${ }^{53}$ In other words, the term "price" as used in the Act "takes into account all discounts, rebates, allowances and other terms and conditions of. sale" which manifestly are the equivalent of a price discrimination. ${ }^{54}$

In the Corn Products case ${ }^{55}$ that company was charged with violation of Section 2 (a) because it utilized a basing point system pursuant to which all its customers paid freight on glucose purchased from the Company on the basis of the freight rate from Chicago to the place of business of the respective customer, whether the glucose was actually shipped from the Company's Chicago plant or from its Kansas City plant. All the customers involved used the glucose in manufacturing candy and regardless of the part of the country in which they were variously located, such customers were in competition with one another. Depending on the destination point, the Company's use of this Chicago basing point system meant the payment by customers served from Kansas City of a "phantom". or fictitious freight charge of from 4 to 40 cents per hundredweight of glucose or from $2 \%$ to $19 \%$ of the Chicago base price. Since glucose was found to constitute from $5 \%$ to $95 \%$ of the candy products manufactured by the petitioners' customers, and since, due to the low prices of such candy products, it was further found that even a fraction of a cent difference in the manufacturing costs incurred by such customers was sufficient to injure competition, the "phantom" freight charged by the company on Kansas City shipments was deemed to be a price discrimination in violation of Section 2 (a) of the Robinson-Patman Act.

In view of the prolific discussion that has arisen since the Corn Products decision with respect to the legality of various basing point systems, it is very important to note, however, that the Supreme Court did not condemn basing point systems per se as violations of Section 2 (a), but only when two elements are present, to wit: a price discrimination between customers and a probable injury to competition. ${ }^{56}$ (1945).

52. Corn Products Refining Co. v. Federal Trade Commission, 324 U. S. 726

53. Agricultural Laboratories, Inc., 26 F. T. C. 296 (I938).

54. Standard Oil Co., F. T. C. No. 4389 (Dec. 10, I945).

55. 324 U. S. 726 ( 1945 ), cited supra note 52.

56. Id. at 737 . 
On the other hand, in the companion case of Federal Trade Comm. v. A. E. Staley Mfg. Co. the court said:

"But it does not follow that respondents may never absorb freight when their factory price plus actual freight is higher than their competitor's price or that sellers, by so doing, may not maintain a uniform delivered price at all points of delivery, for in that event there is no discrimination in price." (Italics ours.) ${ }^{57}$

In other words, uniform pricing of commodities is not of itself a violation of the Robinson-Patman Act. The same is true of a basing point system. Whether or not a violation exists depends upon the probability of injury to competition. Thus, a uniform price system under which prices are the same in a given area, but different as compared with other areas may be illegal because of the impact of higher prices on customers in a higher price area who are in competition with those in a lower price area. No such possible injury to competition will result, however, in the case of a national uniform delivered price which results in a "uniform delivered price at all points of delivery, for in that event there is no discrimination in price." This distinction will serve to clarify and reconcile the statement in the Corn Products case that a uniform delivered price system is not illegal per se, implying that it might be illegal, depending upon particular circumstances, and the statement in the Staley case in respect to a system of uniform delivered prices at all points which, of itself, is legal.

Confirmation of the foregoing explanation is found in the recent case of Aetna Portland Cement Co. v. Federal Trade Comm., ${ }^{58}$ where the court overruled the Federal Trade Commission's "cease and desist" order restraining 74 cement producers from the use of a multiple basing point system in the marketing of cement. The Commission had charged that the cement producers associated in the Cemrent Institute had combined and agreed to use a multiple basing point system of pricing, resulting in the quotation of an identical delivered price by all producers at any given destination allegedly in violation of Section 5 of the Federal Trade Commission Act. Mill $\mathrm{A}$ with a basing point at Town $\mathrm{A}$, the Commission charged, when going into Town $\mathrm{C}$ for business, absorbed freight, a very substantial factor in the final delivered price of cement in order to compete with Mill C; likewise, Mill C with a basing point at Town $\mathrm{C}$, in competing with Mill $\mathrm{A}$ in Town $\mathrm{A}$, absorbed freight and sold at the same delivered prices as Mill A; finally, Mill $B$ located in Town B, which $B$ determined would be a non-basing point, adopted the freight charges of either $A$, or $C$.

57. 324 U. S. 746, 757 (I945).

58. 157 F. (2d) 533 (C. C. A. 7 th, 1946). 
In contrast, however, the "phantom" freight charged by Mill B was found to be in violation of the Robinson-Patman Act. The court concluded in this respect:

"Undoubtedly this constitutes a discrimination against its customers in those towns and is a violation of Sec. 2 (a) of the Clayton Act, as interpreted by the Supreme Court in Corn Products Company v. Federal Trade Commission, 324 U. S. 726 . . ., and Federal Trade Commission v. Staley, 324 U. S. 746 . . ., and the Commission could proceed against $\mathrm{Mill} \mathrm{B}$ and all others engaging in a similar practice." 59

It will be observed that a national uniform price system and certain other pricing systems which do not reflect true freight cost to the seller involve economic discriminations. ${ }^{60}$ The Federal Trade Commission so argued in its findings in the Cement case. ${ }^{61}$

Followed to its ultimate conclusion, the economic theory and reasoning of the Federal Trade Commission in the Cement case as first advanced by the Commission in the "Pittsburgh Plus" proceeding against U. S. Steel in $1924^{62}$ would mean that competition by industry on a national scale would be substantially curtailed. An industry would not be permitted to include in its initial basic price any cost factors, principally transportation, attributable only to portions of its business emanating at distant points. At such points other local industries would control the market and, by the same token, would not be able to compete in distant points. This would mean the fostering by the government of local competitive industry and the limitation of large national competitive industries which have been one of the most notable factors in our industrial progress. ${ }^{63}$

59. $I d$. at 558 .

60. Sharp, Cost Discrimination and the Robinson-Patman Act (1938) 5 U. of CHr. L. Rev. 383; Withrow, Basing-Point and Freight-Zone Price Systems Under the Anti-Trust Lazes (1937) 85 U. of Pa. L. Rev. 690; Fetrer, The Masquerade of MONOPOLY (I93I).

6r. The Court answers this argument at 157 F. (2d) 533,560 (C. C. A. 7th, I946) :

"The finding [of the Commission] continues: 'Each mill shrinks its mill net by the amount necessary for it to match the delivered prices established pursuant to the aforesaid pricing system.' This is high sounding language, perhaps consistent with economic thinking, but in reality it means nothing more or less than that each mill reduces its mill net by the amount necessary to enable it to meet the delivered price of a competitor in territory where it is at a disadvantage freightwise."

.62. Federal Trade Comm. v. U. S. Steel Corporation, 8 F. T. C. I (Ig24). See Sharp, Discrimination and the Robinson-Patman Act (1938) 5 U. oF CHI. L. REv. 383. For fuller exposition of the Federal Trade Commission theory, by its apparent progenitor, a witness for the Commission in the U. S. Steel proceeding, see FETTER, THE MASQUERADE OF MONOPOLY (I93I).

63. The court took cognizance of this situation in the Aetna Portland Cement case, cited supra note 58 , at 563 :

". . . One of its favorite themes is that the basing point system operates to nullify the natural advantages and disadvantages of location of the respective mills 
The Cement Institute decision further enunciated the fact first set forth in the Supreme Court's dictum in the Staley case: ${ }^{64}$ that the economic discriminations inherent in a pricing system are not necessarily illegal discriminations, a point most important for the lawyer to discern in analyzing the legality of any given pricing system. Such economic discriminations are illegal only when they adversely affect competition, that is, one purchaser's ability to sell his products on an equal price basis with his competitor. ${ }^{65}$

The Supreme. Court's dictum in the Staley case translated to the language of the economist, means, for example, that a seller may total outgoing freight costs on finished products shipped to customers (just as he does incoming freight costs on original production materials), add his total production costs and desired profit margin, and arrive at a uniform delivered price equally applicable to all competitive customers since, despite the resultant economic discrimination against customers located nearest to his plant, in that situation, legally, there would be no discrimination in price; and the decision in the Cement Institute case, further clarifying the seller's right with regard to pricing, means that a seller has the right to set his own basic price and to absorb freight in order to meet competition in good faith, although with consequent reduction of his net yield and resultant indirect discrimination against customers nearest his plant, rather than being required to subtract the amount of absorbed freight costs on his most distant shipments from his established basic price and to consider the resultant reduced net yield as his basic price. On the basis of the court's analysis, it may be said, that the Commission or other aggrieved party, has no right to look into the elements making up the seller's established basic price, although, on the other hand, the seller has no right, of course,

when quoting in a given territory. The Commission states: 'Under any kind of pricing method every mill has a substantial and naturally inherent advantage when quoting on nearby business in real competition with more distant mills. By the same token every mill has a substantial and naturally inherent disadvantage when quoting on distant business in competition with mills located nearer to the customer.' This appears to be a logical statement but the question immediately arises as to how the Commission proposes to give effect to this 'naturally inherent advantage' and this 'naturally inherent disadvantage.' As we have already shown, it proposes to make supreme the advantage of a mill selling in the territory where it has a freight advantage, and to make its disadvantage so great when selling in a competitor's territory as to practically preclude it from entering that market. In fact, the advantage and disadvantage would no longer be natural but artificial; effected by the requirement that each mill sell on an f.o.b. mill price. The change from the present system to one conforming with the Commission's order would be like jumping from the frying pan into the fire."

64. Cited sipra note 57.

65. Corn Products v. Federal Trade Comm., cited note 39 supra; Federal Trade Comm. v. Staley, cited note 57 supra. See Book Note (I93I) 45 HARv. L. REv. 397; also Withrow, Basing-Point and Freight-Zone Price System Under the Anti-Trust Lawes (1937) 85 U. OF PA. L. REv. 690, for review of applicable basing-point decisions of the courts up to that time. 
to give any special discriminatory discount or markdown from such price to particular customers as earlier considered herein. ${ }^{66}$

Legislative cognizance has been taken of the economic discriminations inherent in many basing point systems, but no final action has ever been taken. ${ }^{67}$ Accordingly, the court concluded in the recent Cement case: ${ }^{\text {ss }}$

"If this pricing system which Congress has over the years steadfastly refused to declare illegal, although vigorously urged to do so, is now to be outlawed by the courts, it will mark the high tide in judicial usurpation."

Significant by way of contrast with the recent Cement decision are the decisions of the same Circuit Court in United States Malsters Association et al. v. Federal Trade Comm., ${ }^{69}$ and Milk and Ice Cream Can Institute v. Federal Trade Comm. ${ }^{70}$ Of these cases, the Circuit Court of Appeals for the 7 th Circuit said in the Cement case: ${ }^{71}$

"We need not discuss these decisions any further than to point out that in each of those cases a conspiracy to fix prices was charged and found. The multiple basing point price system was not directly involved in either case. In other words, the conspiracy was to fix prices and not merely to use a system from which uniformity of price resulted, as in the instant case and the old Cement case."

Judge Evans in his dissenting opinion emphasized that an agreement to fix prices by use of a multiple basing point system was the heart of the case, however, and that since the Federal Trade Commission had found sufficient evidence to support the existence of such an agreement, it was not the function of the court to reverse the finding. It is too well recognized to need comment that any understand-

66. For a comparison with the Circuit Court's disposition of the economic verbiage surrounding the situation, see the analysis of Prof. Fetter's economic concept, Book
Note (I93I) 45 HARV. L. REv. 395.

67. In Aetna Portland Cement Co. v. Federal Trade Comm., 157 F. (2d) 533 (C. C. A. 7 th, 1946) the court said at p. 573 :

“. . . the basing point price system has been in use by industry for almost a half century. . The pages of the Congressional Record bear mute but indisputable proof of the fact that Congress has repeatedly refused to declare its use
illegal.

"In our judgment, the question as to whether the basing point price system should be declared illegal rests clearly within the legislative domain."

68. Ibid.

69. I52 F. (2d) I6I (C. C. A. 7th, 1945).

70. 152 F. (2d) 478 (C. C. A. 7 th, 1945).

7 r. Cited supra note 58 , at 572 . 
ing or agreement which makes use of a basing point system to fix prices is illegal. ${ }^{72}$

The consideration given by the courts to the matter of basing point and delivered price systems as possible means of price discriminations demonstrates at any rate the wide scope of Section 2 (a) of the Robinson-Patman Act with respect to the meaning that will be given to "price discriminations." The same point is evidenced also by the fact that the Supreme Court in the Corn Products case considered as price discriminations forbidden by Section 2 (a) the company's "price protection" practice of permitting certain favored customers to take delivery of glucose at the old prices, after new, higher prices were generally in effect, as well as the company's fictitious "quantity price" practice of permitting certain tank wagon customers to book orders at the lower prices charged for tank car deliveries when deliveries were actually taken by tank wagon quantities over extended periods of time and no cost savings were therefore realized by the seller. In answer to the contention of the petitioners that the practices were discriminations in the "terms of sale" but not in price, the court said:

“. . . we cannot ignore the fact that the present discriminations in the terms of sale operated to permit the favored customers to - purchase at a lower price than other customers so that their only practical effect was to establish discriminations in price, precisely the evil at which the statute was aimed." 73

The term "direct and indirect discrimination" is, therefore, broad enough and was designed to embrace any variation of price discrimination 'and any equivalent practice which might be devised to evade the prohibition against price discrimination. ${ }^{74}$ If a seller gives credit terms to one purchaser, however, while refusing to give such terms to another purchaser, no indirect discrimination is effected because the two customers involved, due to the respective situation of each, may not be entitled to the same consideration on this score. Nevertheless, if a purchaser makes payment in the same way and at the same time as other purchasers, he is entitled to the same discount that may be available to such other purchasers for prompt payment. ${ }^{75}$ Significantly, the openness or secrecy surrounding a price differential will be very important in determining its legality. If a price discrimination of 558.

72. See Note, Basing-Point Pricing and Anti-Trust Policy (I946) 55 YaLE L. J.

73. Cited supra note 55 , at 740 . REv. I3I.

74. Bayley, Four Years Under the Robinson-Patman Act (I94I) 25 MInN. L.

75. Note, The Robinson-Patman Act in Action (1937) 46 Yare L. J. 447, 463-64. 
any type is secretly given to a buyer it probably will be deemed illegal. ${ }^{76}$

The foregoing discussion logically suggests the question therefore: What precisely is "discrimination"?

While the term seemingly might have been more logically considered before a discussion of the term "direct and indirect discrimination," it has been deemed preferable to consider the term "discrimination" at this point because of the competitive relationship implied by the term. This, in turn, naturally leads to a consideration of the various types of competitive relationships comprehended by the Act, for the Act does not make unlawful mere differences in price between purchasers, but only differences which amount to "discrimination." 77

An analysis demonstrates that there are two elements that exist with respect to a prohibited price discrimination. The essential discrimination is found in the fact that two or more customers buy from the seller the same commodity produced at the same expense to the seller and yet pay different prices. Next, this discrimination affects the competitive relationship between these two parties, i. e., one person, whether a buyer or a seller, is competitively injured by the discrimination.

In regard to the fifth element, the element of competitive injury that must exist in an act violative of Section 2 (a), the Section provides that a discriminatory act or practice is proscribed "where the effect of such discrimination may be substantially to lessen competition or tend to create a monopoly in any line of commerce, or to injure, 'destroy or prevent competition with any person who either grants or knowingly receives the benefit of such discrimination, or with customers of either of them." While injury to competing purchasers from the same seller is most commonly involved in cases under the Robinson-Patman Act, ${ }^{78}$ it is not the only type of competitive injury which may be involved in a price discrimination forbidden by the Act. Another type is to be found in sales by a seller at discriminatory prices to some customers (even though these are not in competition with his other customers) where the probable effect of the discrimination may be

76. American Can Co. v. Ladoga Canning Co., 44 F. (2d) 763 (C. C. A. 7th, I930), cert. denied, 282 U. S. 899 (I930); Sugar Institute v. United States, 297 U. S. 553 (I936), aff'g., I5 F. Supp. Si7 (S. D. N. Y. 1934); United States v. Great Atlantic \& Pacific Tea Co., 67 F. Supp. 626 (E. D. Iil. I946).

77. Mr. Utterback stated in the House upon submission of the conference report on the bill, So CoNG. Rec. 9416 (1936):

"In its meaning as simple English a discrimination is more than a mere difference. Underlying the meaning of the word is the idea that some relationship exists betwen the parties to the discrimination which entitled them to equal treatment, whereby the difference granted to one casts some burden or disadvantage upon the other." (Italics ours.)

78. Corn Products Refining Co. v. Federal Trade Commission, cited supra note 55. 
to injure a competing seller. ${ }^{79} \mathrm{~A}$ variation of the latter type of competitive injury is found in the case where a seller sells at discriminatory prices to some of his customers (even though they are not in competition with his other customers) where the effect of the discrimination may probably be to injure the customers of a competing seller.

It follows, therefore, that the seller who wishes to determine whether his prices and distribution practices are in conformity with the Robinson-Patman Act must examine to some extent the prices and practices of his competitors as well as the effect which his acts may have on his own customers.

Once a competitive relationship is established and there is probability of injury to competition as a result of a discriminatory act, the competitive factor requisite for a violation of the Act is present regardless of how far apart or how near the competitive parties may be geographically. This was made clear by the Supreme Court in the Corn Products case, in answering the Company's objections that its Chicago basing point system did not violate the Act since all purchasers in a given locality paid exactly the same freight charges on the glucose which they purchased. ${ }^{80}$

Nor is it necessary that more than one competitor; whether a seller or a purchaser, be injured or threatened with injury by the discriminatory act. If one person is injured he will have the right to injunctive relief and to an action for treble damages. Injury or threatened injury to several persons (that is involvement of the public interest) is the recognized requisite only for intervention by the.Federal Trade Commission, ${ }^{81}$ although even then a direct injury to one competitor may be sufficient for action by the Federal Trade Commission if only a few competitors are engaged in the field! 82

Care is taken to use the expression "injury or threatened injury," it will be observed, since it is now clear that the statute does not require that the discrimination must in fact have harmed competition, but only that there is a reasonable possibility that the discrimination practiced might have such an effect. ${ }^{83}$ It is equally clear, of course, that a mere possibility of injury to competition is not a sufficient basis for a violation of the Act. ${ }^{84}$ The injury or threatened injury on which the

79. Samuel H. Moss., Inc. v. Federal Trade Comm., I48 F. (2d) 378 (C. C. A. 2 d, I945), cert. denied, 66 Sup. Ct. 44, and in Midland Oil Co. v. Sinclair Refining Co., $4 \mathrm{I}$ F. Supp. 436 (N. D. III. I94I).

8o. Cited supra note 55 , at 734 .

8I. 38 Stat. 7 I9 (19I4), amended, 43 Stat. 939 (1925), 52 Stat. III (I938), 15 U. S. C. $\$ 45$ (b) (1940). I944).

82. Muller v. Federal Trade Commission, I42 F. (2d) 5II, 520 (C. C. A. 6th,

83. Corn Products Refining Co. v. Federal Trade Comm., cited note 55 supra.

84. 49 Stat. I526 (1936), I5 U. S. C. \$ I3 (a) (1940). 
violation is based must, in any event, however, be substantial whether the injury charged is with respect to only one person or with respect to competition generally. De minimis non curat lex. While ordinarily discriminations involving small amounts will not be deemed violations of the Act, this should not be interpreted to mean that reliance can be safely placed on figures and percentages alone. Cognizance may well be taken of a systematic number of small discriminatory discounts, all of which together amount to a discrimination sufficiently large to substantially injure competition or a competitor. ${ }^{85}$ Cognizance may be taken also of the fact that though a discrimination in and of itself is small in amount, it may be sufficient in certain circumstances to injure competition substantially. Thus in United States v. New York Great Atlantic and Pacific Tea Co., the court remarked that the difference between profitable operation and loss in the retail food business is fractional in character, so that any dealer who secured an unfair advantage over his competitors, however small it might be, would be likely to upset or reverse a small percentage of profit in his competitor and convert it into a loss. Accordingly, the court concluded that "when the net profit is in the neighborhood of $2 \%$, an advantage of $5 \%$ in buying in one dealer immediately places him in an over-powering position so far as his competitors are concerned." 86

\section{Quantity Discounts}

It is not true, nevertheless, that discriminatory discounts or prices are always forbidden by the Act even where competition may be injured. Quantity discounts specifically are exempted from the application of Section 2 (a) if justifiable on the basis of cost savings. In this regard, the Act does not require that cost savings due to quantity production or distribution must be passed on by the seller to the buyer, but does require that when price differentials based on quantity are granted, they must reflect cost savings to the seller. ${ }^{87}$ A mere arbitrary allocation or imputation of costs and savings is not permissible. ${ }^{s s}$ (Mr. Utterback in the House of Rep., after submission of conference report, 8o Cong. REc. 9560 (I936)). For this reason, the purchasers of the units of a chain store may not be bulked for purposes of granting a volume discount based on the total volume of all the units when deliveries are made to the units and no saving to the seller in cost of delivery is

S5. American Can Co. v. Ladoga Canning Co., 44 F. (2d) 763 (C. C. A. 7th, I930).

86. It follows that the test in the final analysis is not one of numerical amount or degree, but only of substantial effect on competition. See Corn Products Co. v. Federal Trade Comm., I44 F. (2d) 2II, 2I6 (C. C. A. 7th, I944).

87. H. R. ReP. No. 295I, 74th Cong., 2d Sess. (I936).

88. Mr. Utterbach in the House of Rep., after submission of conference report, 80 CONG. REC. 9560 (1936). 
effected. ${ }^{89}$ Nevertheless, cost savings reflected in quantity discounts can be indirect and approximate rather than precisely commensurate with the price differential..$^{90}$ Items of the following type, for example, may be considered in computing and reflecting cost savings in quantity discounts : savings in packaging costs on large orders; ${ }^{91}$ savings in paper and clerical work reasonably allocable to large orders ; ${ }^{92}$ sayings in handling, storage, sales, and transportation expense on large orders; savings due to placing of orders long in advance; and savings in overhead reasonably related to volume purchases; ${ }^{93}$ probably; also, the division by the seller of his business into separate enterprises, one of which sells exclusively to large customers. ${ }^{94}$

If the quantity price discount bracket is set at a point sufficiently low to allow substantially all purchasers actually to take advantage of it even though actually they do not so do, the quantity discount will, of course, be justifiable since there will be neither discrimination nor probability of injury to competition. ${ }^{95}$ Care must be taken in this connection, however, that all purchasers can actually take advantage of a preferential price offer ${ }^{96}$ and that purchasers are not merely ostensibly able to take advantage of a price discount. ${ }^{97}$

The same rules that apply to ordinary quantity discounts are equally applicable to cumulative volume discounts, that is, to discounts based on a buyer's total purchases over a given period and granted retroactively, although it will undoubtedly be much more difficult to justify cumulative volume discounts than quantity discounts based on the quantity purchased at one time since the relation of cost savings is substantially more remote.

\section{Functional Discounts}

Like quantity discounts, certain functional discounts may be deemed also exempt from the application of Section 2 (a) of the Act, but for other reasons, although the Act itself does not mention the sub-

89. Life Savers Corp., 34 F. T. C. 472 (I94I) ; United States Rubber Co., 28 F. T. C. 1489 (1939) ; Simmons Co., 29 F. T. C. 727 (1939).

90. Sugar Institute v. United States, 297 U. S. 553 (I936), aff'g., I5 F. Supp. 8I7 (S. D. N. Y. I934); Goodyear Tire and Rubber Co., 22 F. T. C. 232 (I936); Note, "The Robinson-Patman Act in Action" (r937) 46 YALE L. J. 447, 460.

9r. Corn Products Refining Co. v. Federal Trade Commission, cited supra note 55.

92. Sugar, Institute v. United States, 297 U. S. 553 (I936).

93. Ibid.

94. Smith, Patman Act in Practice (1937) 35 MicH. L. Rev. 705, 720. REv. I3I.

95. Bayly, Four Years Under the Robinson-Patman Act (I94I) 25 MrNN. L.

96. Elizabeth Arden, Inc., et al. v. Federal Trade Commission, I56 F. (2d) I32

(C. C. A. 2d, 1946).

97. Corn Products Refining Co. v. Federal Trade Commission, cited supra note 55. 
ject. $^{98}$ True functional discounts will not adversely affect competition. In addition, many functional discounts are justifiable on a cost basis.

Where a seller gives functional discounts to two really different classes of customers who operate exclusively in different channels of trade, no probability of injury to competition is involved. Thus, two or more purchasers from the same seller performing entirely different functions in respect of their purchases, such as a wholesaler selling exclusively to retailers, a retailer selling exclusively at retail, and a manufacturer using the commodity involved exclusively in the production of a new end product and not selling the original commodity as such either at wholesale or retail, ${ }^{99}$ do not compete with one another. It would likewise follow that where the facts were in line with those indicated, the true wholesaler, being distinguished by the character of his exclusive selling in a channel of trade not competitive with that of the retailer and not by the quantity of his buying, might properly receive a wholesale discount regardless of the quantity in which he purchased.

It is true, of course, that if a manufacturing seller gave to an $e x$ clusive wholesaler a discount disproportionate to the value of the services performed by the wholesaler so as to enable the latter to give to retailers who purchased from him better prices than were available to competitive retailers buying directly from the manufacturing seller, a possible violation of the Act might occur. But, quite pragmatically, a manufacturing seller would not be inclined to sell to wholesalers and retailers and to give prices to those of the former class that would enable them to destroy the seller's own competitive position with respect to his retailers. On the other hand, if special discounts to his wholesalers were necessitated by the pressure of competitive circumstances, the seller would undoubtedly choose either to sell exclusively to wholesalers or exclusively to retailers.

The principal difficulty as respects wholesale functional discounts arises not where the wholesaler is a true exclusive wholesaler, but

98. Klepinger, Wholesalers and the Robinson-Patman Act (1946) 50 L. Notes No. $2,23$.

99. The language of the Court in S. S. Kresge Co. v. Champion Spark Plug Co., 3 F. (2d) 4 I5 (C. C. A. 6th, I925) seems applicable in this respect since the basic point as to whether or not competition is affected was involved in that case, although Section 2 of the original Clayton Act rather than Section 2 (a) of the present RobinsonPatman Act, was the statute involved. Referring to the Clayton Act and to the granting by the seller of lower prices on its products to car manufacturers than to replacement suppliers, the court said at p. 420 :

"That Act-rightly interpreted-forbids discrimination in price between purchasers only where the effect may be unreasonably to lessen competition or tend to create a monopoly, which we think is not shown to be the case here. The price of the car to the original purchasers is presumably lessened by the low prices paid for factory equipment. The replacement price is not necessarily thereby increased above the normal from the mere fact that the loss incurred in providing factory equipment must be overcome by replacement prices. The field is open to all fair competitors." 
rather where the wholesaler does also a substantial retail business either through his wholesale place of business or through separate retail outlets and thus competes with retailers buying from the same manufacturing seller. Difficulty arises also when a purchaser is arbitrarily designated by a seller as a "wholesaler" or is not required by contract with the seller to perform any distinctive distributing functions for the seller or incur any extra expenses in connection therewith as compared with the competitive retailer. It is these situations that generally give rise to questions concerning the propriety of functional discounts. Such situations more properly come within the sphere of the discussion regarding cost justification for functional discounts immediately following.

A demonstration of cost savings constitutes a defense to price differentials generally and is equally available as a defense when the price differentials are designated as functional differentials. More favorable discounts may be granted to wholesalers, for example, when such discounts are commensurate with cost savings to the seller in doing business with wholesalers who generally order in advance and with regularity and buy their stock in large quantities. Discounts or price differentials so justifiable are legal regardless of effect on competition since they are not discriminations forbidden by the Act. ${ }^{100}$

Conversely, it follows from what has been said that in cases where wholesale prices do not reflect cost savings to the seller, a wholesaler, who also conducts a retail business in competition with retailers, may

- be granted a wholesaler's price only on those items which he buys and resells at wholesale, and that on items resold at retail he may be granted only the same over-all net prices as are obtainable by the retailers in competition with him. This does not mean necessarily that the volume of such a purchaser must be segregated into wholesale and retail and that wholesale and retail discounts, respectively, must be granted only in respect of such segregated volumes since the law is not concerned with any formula but only with the final criterion as to whether or not a probability of injury to competition results. Sales

100. Section 2 (a) of the Act, first proviso, says:

". . nothing contained in sections I2, I3, I4-2r, 22-27 of this title shall prevent' differentials which make only due allowance for differences in the cost of manufacture, sale, or delivery resulting from the differing methods or quantities in which such commodities are to such purchasers sold or delivered."

For a further discussion of functional discounts see: Standard Oil Co., F. T. C. No. 4389 (Dec. IO, I945) ; 22 WASH. U. I. Q. I53. Also United States Quary Tile Co., 32 F. T. C. 1652 (I94I) ; Superior Ceramic Corp., 32 F. T. C. I652 (I94I); Mosaic Tile Co., 32 F. T. C. I653 (I94I) ; Pardee Matawan Tile Co., 32 F. T. C. I654 (I94I); Wenczel Tile Co., 32 F. T. C. I654 (I94I); Wheeling Tile Co., 32 F. T. C. I655 (I94I) ; Architectural Tiling Co., 32 F. T. C. I655 (I94I); National Tile Co. Inc., 32 F. T. C. I656 (I94I). 
to wholesalers who do a substantial retail volume, therefore, may be safely handled in any one of three ways.

First, such a purchaser's volume might be divided into wholesale and retail and the same basic discount granted to him on all his purchases together with an overriding wholesale discount on those of his purchases resold at wholesale. While this would perhaps best satisfy the Act from a technical standpoint, actually it will usually be found difficult to administer even though the seller will evidently be required to exert only a reasonable effort to police the system. ${ }^{101}$ The seller might require the purchaser to submit at given intervals certified copies of his wholesale and retail volume, but expense, delay, and trouble would undoubtedly be encountered in checking the statements of the purchaser and, in addition, human nature being what it is, the purchaser might well be tempted for profit reasons to err in submitting figures on his wholesale volume. The necessity of resorting to this method in order to compensate the purchaser for the use made of commodities purchased was criticized by Commissioner Mason in a novel and startling dissent in the Standard Oil case, ${ }^{102}$ but nevertheless meets with Federal Trade Commission approval as represented by the majority opinion in the same case.

Secondly, the purchaser might set up two separate corporate enterprises, one substantially a wholesaler, the other substantially a retailer, and the seller might give to each its respective functional discount. Since the Act requires as a condition to violation thereof that there be two competitive purchasers from the same seller, ${ }^{103}$ no violation apparently could exist in this type of situation since the wholesale corporation would not be in competition with retailers engaged in competition with the purchaser's retail corporation. Even if the purchaser did not go so far, however, as to set up separate corporate enterprises, but merely set up different operating divisions of its business, one to handle wholesale and one to handle retail, probably the purchaser and seller would also avoid violation of the Act since in that event the parties would be acting essentially in accordance with the first method of approach to the problem.

Thirdly, instead of giving the purchaser a large enough discount on his purchases for resale at wholesale to take care of his expenses in

ror. Standard Oil Co., F. T. C. No. 4389 (Dec. I0, 1945).

I02. Ibid.

I03. See consideration, supra, at 3 Io, of the requirement under $\$ 2$ (a) of the Act that there must be two purchasers from the same seller. In view of the government's arguments in the $A . \& \mathcal{F} P$. case, in regard to the establishment of separate corporations to avoid the impact of the Robinson-Patman Act, some attack on the practice here discussed might be anticipated of course. 
connection therewith, plus a reasonable profit, it would appear that the seller might give to such a purchaser a flat discount in a lesser amount on all his purchases whether subsequently resold by him at wholesale or retail. By thus averaging the over-all discounts, the purchaser would be put in the same position as if a preferential discount were given to him on his "wholesale purchases" only, and a retail discount given to him on his "retail purchases." This is probably the most practical approach to satisfying the requirements of the Act. It necessarily involves, of course, setting up some requirements to be complied with by the purchaser so that the average price granted to him on his purchases will result in a fair averaging of prices to him on his over-all business as compared with other purchasers doing solely a wholesale or solely a retail business. For example, the purchaser, may be required to do a certain percentage of business at wholesale and may be required to maintain wholesale facilities and carry out the functions of a true wholesaler. The establishment of specific requirements along the foregoing lines will be desirable to remove the possibility of any charge that the special discounts given by the seller are unrelated to costs of the seller or of the buyer. It is quite clear from the position that Commissioner Mason took in his dissenting opinion in the Standard Oil Company case-which in this respect is reconcilable with the majority opinionthat this approach to the wholesale discount problem in the case of a wholesaler doing a retail business will meet with Federal Trade Commission approval. ${ }^{104}$

\section{Other Exempt Practices}

In addition to permissible price differences that may exist in respect to quantity discounts and functional discounts certain other price differences to customers are also permissible under the Act. Sales at special prices to the Government are unobjectionable since the Government is not a competitive customer. ${ }^{105}$ Sales by a seller to a branch store are exempt since there is no "purchase" or "sale" involved. ${ }^{106}$ Sales for final consumption by retail customers are exempt because retail customers are not in competition with one another commercially;

I04. In the Standard Oil case the Standard Oil Company classified four of its customers as jobbers, although it did not require them to perform any jobber functions. Attempting to defend the preferential prices given to these customers, the Standard Oil Company sought to impute cost savings to its manner of dealing with these customers as compared with other customers, but such imputations of cost savings were found to be without foundation in fact.

105. General Shale Products Corp. v. Struck Construction Co., 37 F. Supp. 598 (W. D. Ky. I94I), aff'd., I32 F. (2d) 425 (C. C. A. 6th, I942), cert. denied, 3 I8 U. S. 780 (1943).

I06. Jarrett v. Pittsburgh Plate Glass Co., I3I F. (2d) 674 (C. C. A. 5th, I942). 
sporadic sales as distinguished from regular sales of a given commodity are for the same reason also exempt: ${ }^{107}$

"The Act . . . applies to commercial sales on the part of those who deal in the commodity under consideration to purchasers from a seller."

However, the Act does cover sales to two or more purchasers of a commodity used or consumed by purchasers in or in connection with the manufacture or processing of an end product which is sold by them in competition with one another. Thus, in Van Camp \& Sons $v$. American Can Co., ${ }^{108}$ and American Can Co. v. Ladoga Canning $\mathrm{Co} .{ }^{109}$ the cans involved were not resold by the canning companies, but were used in connection with the sale of other items. In the Corn Products case and in the Staley $M f g$. Co. case, glucose, the commodity involved, was not resold by the competitive purchasers but was used by them as an ingredient in the products manufactured by them and in turn resold in competition.

\section{SeCtIONS 2 (C), 2 (D) AND 2 (E)}

Discriminations forbidden by the Robinson-Patman Act, as observed at the outset, are of two types: first, the general acts of price discrimination whose illegality is dependent on their probable injurious effect on competition-these are forbidden by Section 2 (a); second, specific acts which Congress has adjudged to be inevitably injurious to competition-these are forbidden by Sections 2 (c), 2 (d) and 2 (e).

Section 2 (c) of the Act prohibits a seller from paying fictitious brokerage fees either directly or indirectly to the buyer or to the buyer's agent or intermediary. The receipt of such fictitious brokerage payments is likewise prohibited by the Section. ${ }^{110}$

Section 2 (d) ${ }^{111}$ prohibits discriminatory payment to a buyer for services and facilities furnished by such buyer where comparable, proportionate payment is not made or offered to another buyer for similar services. Section 2 (e) ${ }^{112}$ complements Section 2 (d) in prohibiting a seller from furnishing discriminatory services to a buyer.

I07. General Shale Products Corp. v. Struck Construction Co., 37 F. Supp. 598, 602 (W. D. Ky. I94I).

108. 278 U. S. 245 (I929).

109. 44 F. (2d) 763 (C. C. A. 7th, r930). These cases, while decided prior to the amendment of Section 2 of the Clayton Act by the Robinson-Patman Act, were based upon comparable language in the old section.

IIo. For language of Section 2 (c), see note $I \pi$, supra.

III. For language of Section 2 (d), see note 12, supra.

II2. For language of Section 2 (e), see note 13, supra. 
These three subdivisions of the Act have in common the fact that they are applicable to all sales in foreign or interstate commerce. In this respect they are similar to Section 2 (a) of the Act. Unlike Section 2 (a), however, these sections evidently apply to all sales in foreign or interstate commerce, regardless of whether or not the commodities involved are "sold for use, consumption or resale in the United States," since the quoted language which appears in Section 2 (a) does not appear in these sections. Actually, it is to be noted, there is no reference in Section 2 (e) whatever to the type of commerce involved, as is true with respect to the other sections of the Act, and for this reason Section 2 (e) has been attacked, although unsuccessfully, as unconstitutional. ${ }^{113}$

Sections 2 (c), 2 (d), and 2 (e) are alike also in that the acts prohibited thereby are inherently illegal by decree of Congress, regardless of effect on competition.

Section 2 (c) was enacted to prohibit the unethical practice of forcing a seller to pay a brokerage fee to a broker designated by the buyer and the practice of having a broker divide his allegiance between the two parties to a contract. ${ }^{114}$. Accordingly, fictitious brokerage fees of any kind are absolutely proscribed on the basis that they are inherently injurious to the free flow of commerce and, therefore, unlawful per se. ${ }^{\mathbf{1 1 5}}$

The same illegality per se exists with regard to the acts condemned by Sections 2 (d) and (e). In Oliver Bros. v. Federal Trade Comm., ${ }^{116}$ the court said regarding these sections:

"It is perfectly clear that all three of these practices were forbidden because of their tendency to lessen competition and create monopoly, without regard to their effect in a particular case; and there is no reason to read into the sections forbidding them the limitations contained in Section 2 (a) having relation to price discrimination, which is an extremely difficult matter to deal with and is condemned as unfair only in those cases where it has an effect

II3. E. Arden, Inc. v. Federal Trade Commission, I56 F. (2d) I32 (C. C. A. 2d, I946); Elizabeth Arden Sales Corp. v. Gus Blass Co., I50 F. (2d) 988 (C. C. A. 8th, I945).

II4. Oliver Bros. v. Federal Trade Comm., I02 F. (2d) 763 (C. C. A. 4th, I939); Bayly, Four Years Under the Robinson-Patman Act (r94I) 25 MINN. L. REv. I3I.

II5. Southgate Brokerage Co., Inc. v. Federal Trade Comm., 150 F. (2d) 607 (C. C. A. 4th, I945); Great Atlantic \& Pacific Tea Co. v. Federal Trade Comm., I66 F. (2d) 667 (C. C. A. 3d, 1939), cert. denied, 308 U. S. 625 (1940), rehearing denied, 309 U. S. 694 (1940); Quality Bakers of America v. Federal Trade Comm., II4 F. (2d) 393 (C. C. A. Ist, I940) ; Oliver Bros. v. Federal Trade Comm., IO2 F. (2d) 763 (C. C. A. 4th, I939); Biddle Purchasing Co. v. Federal Trade Comm., 96 F. (2d) 687 (C. C. A. 2d, I938), cert. denied, 305 U. S. 634 (I938) ; Kentucky-Tennessee Light \& Power Co. v. Nashville Coal Co., 37 F. Supp. (W. D. Ky. I94I).

II6. I02 F. (2d) 763,767 (C. C. A. 4th, I939). 
in suppressing competition or in tending to create monopoly. The forbidding of specific practices because of their tendency toward a general result, also forbidden, is familiar legislative practice; and no reason suggests itself why the limitations and provisions relating to one should be read into those relating to the other." 117

Paradoxically, however, competitive practices are a possible defense to a violation of Section 2 (e) as is true of Section 2 (a), although not a defense to a violation of Section 2 (c) or 2 (d). This situation is considered in connection with Section 2 (b) of the Act, infra.

A third feature of similarity in the three Sections under consideration is the fact that indirect as well as direct violations of the Sections are prohibited. Thus, Section 2 (c) specifically prohibits fictitious brokerage payments by a seller not only to a buyer, but also to the buyer's agent or any person under the buyer's control. Interpreting the prohibition in accordance with its spirit, the courts have stated that any payment of compensation by a seller to an agent or representative of the buyer is prohibited and unlawful whether the agent in receiving the commissions is acting in the transaction "in behalf of the buyer or merely for his own pocket". 118 and that a broker who places the orders of a buyer at the most advantageous prices from the standpoint of the buyer and otherwise acts on behalf of the buyer may not accept any brokerage fee from a seller, even though the buyer pays him no fee, if other buyers have to pay fees to brokers for similar services; ${ }^{119}$ and that no broker who owes any allegiance to a buyer can accept any type of brokerage fee from the seller, even though he performs some services for the seller and would otherwise appear to be entitled to compensation within the apparent exception specified in Section 2 (c), to wit:

"It shall be unlawful . . . to pay . . . or to receive... anything of value as a commission, brokerage or other compensation, or any allowance or discount in lieu thereof, except for services rendered in connection with the sale or purchase of goods, wares or merchandise." (Italics ours.)

II7. To the same effect are the following: Corn Products Refining Co. v. Federal Trade Comm., 324 U. S. 726, 746 (1945), I44 F.(2d) 2II, 2I 5 (C. C. A. 7th, I944); Southgate Brokerage Co. v. Federal Trade Comm., I50 F. (2d) 607 (C. C. A. 4th, 1945) ; Great Atlantic \& Pacific Tea Co. v. Federal Trade Comm., Io6 F. (2d) 667 (C. C. A. 3d, 1939), cert denied, 308 U. S. 625 (I940); Oliver Bros. v. Federal Trade Comm., cited supra note II6; Biddle Purchasing Co. v. Federal Trade Comm., 96 F. (2d) 687 (C. C. A. 2d, r938), cert. dentied, 305 U. S. 634.

II8. Fitch v. Kentucky-Tennessee Light \& Power Co., I36 F. (2d) I2, I5 (C. C. A. 6 th, Ig43).

Irg. Federal Trade Comm. v. Herzog, I50 F. (2d) 450 (C. C. A. 2d, I945); see also Modern Marketing Service, Inc. v. Federal Trade Commission, I49 F. (2d) 970 (C. C. A. 7 th, 1945). 
For no true services sufficient to constitute a legal obligation or the basis of a moral obligation can be rendered by a broker except to the person who has engaged him or to whom he owes his first allegiance. ${ }^{120}$ This is sound business ethics as well as sound law.

The most recent and striking recognition of this fact is seen in the $A \& P$ case in which the court found that $\mathrm{A} \& \mathrm{P}$ and its allied defendants were guilty of restraining trade and monopolizing a substantial part of the interstate trade and commerce in food due primarily to the unlawful brokerage activities of its wholly-owned subsidiary, ACCO, the Alantic Commission Company. ACCO at once acted as selling agent for certain produce suppliers, as purchasing agent for $A \& P$, and as buying broker for certain competitors of A \& $P$ and used its inconsistent positions to the advantage of $A \& P$ and the detriment of others. Said the court: ${ }^{121}$

"The conduct of ACCO is the rotten thread of the fabric and it so permeates the entire texture and ties together the other threads as to result in an imperfect, an illegal product-unreasonable interference with competition and power to monopolize."

While Sections 2 (d) and 2 (e) have not received the extensive consideration of courts that Section 2 (c) has received, it is, nevertheless, clear from the specific language of those sections that in an appropriate case the courts would go to similar lengths in prohibiting indirect violations of the Sections. Section 2 (d), for example, prohibits discriminatory payment for services either to the buyer or in any way that is beneficial to the buyer. ${ }^{122}$ It is applicable also not only to a sale and resale of a product in its original state, but in any modified state, since the Act specifically proscribes payment for facilities "in connection with the processing, handling, sale or offering for sale." 123 While the language of Section 2 (e) is not as detailed in this regard, the same limitations may reasonably be inferred since the Section is essentially complementary to Section 2 (e) and has been so interpreted. ${ }^{124}$

I20. Southgate Brokerage Co. v. Federal Trade Comm., I50 F. (2d) 607, 609 (C. C. A. 4th, 1945); Modern Marketing Service, Inc. v. Federal Trade Comm., I49 F. (2d 970, 978 (C. C. A. 7th, I945) ; Quality Bakers of America v. Federal Trade Comm., II4 F. (2d) 393, 399 (C. C. A. Ist, I940); Webb-Crawford Co. v. Federal Trade Comm., rog F. (2d) 268, 270 (C. C. A. 5th, 1940) ; Great Atlantic \& Pacific Tea Co. v. Federal Trade Comm., ro6 F. (2d) 667,674 (C. C. A. 3d, 1939); Oliver Bros., Inc. v. Federal Trade Comm., I02 F. (2d) 763,770 (C. C. A. $4^{\text {th, } 1939) \text {. }}$

I2x. Cited supra note 3 .

122. Section 2 (d) in this connection reads: "It shall be unlawful for any person engaged in commerce to pay or contract for the payment of anything of value to or for the benefit of a customer of such person. . . " (Italics ours.)

123. Corn Products Refining Co. v. Federal Trade Commission, 324 U. S. 726, 744 (1945).

124. In Elizabeth Arden Sales Corp. v. Gus Blass Co., I50 F. (2d) 988, 990 (C.

C. A. 8th, 1945), where a seller engaged in interstate commerce arbitrarily furnished 
In view of the clear and sweeping prohibitions of Section 2 (c) and the interpretations thereof by the courts, there is no real problem for the businessman in determining what steps he must take to be in compliance with the section: Under no circumstances can a broker be granted or accept anything in the nature of a fee from one party to a sales transaction when he owes allegiance to the other party. ${ }^{125}$ In respect to Section 2 (d) and 2 (e), however, some further consideration of possible guides may be necessary, since the businessman will desire to know precisely what he must do to have his advertising practices in conformity with the law.

While Section 2 (d) of the Act was enacted chiefly to stop discriminatory advertising practices, $e$. $g$., the practice of a seller paying one buyer for advertising, demonstrating or displaying his products while offering no comparable and proportionate payment to another buyer for similar services, the Section is not so limited by its language, but applies to discriminatory practices in the nature of sales promotion. ${ }^{126}$ And in keeping with this broad purpose, Section 2 (d) condemns not only an actual discriminatory payment in connection with sales promotion but even a contract for the granting of a discriminatory payment since the section provides that "it shall be unlawful for any person . . . to pay or contract for the payment . . ." 127 In other words, such a contract is void and illegal per se. Hence, it is not enforceable and the parties to it are subject to the penalties provided by the Act.

Certain helpful guides were laid down by the court in Elizabeth Arden Sales Corp v. Gus Blass Co., ${ }^{128}$ and more recently in E. Arden Inc. v. Federal Trade Comm., ${ }^{129}$ to assist the business man in determining whether he was giving or offering his customers proper advertising

clerks' services or salaries in unequal amounts to customers competing in distribution of its products, the court said:

"The situation probably might alternatively have been regarded as a discriminatory payment of compensation by appellant for special clerks' services or facilities furnished by Cohn Co. and by appellee in demonstrating or pushing the sale of appellant's products instead of as a furnishing of clerks' services or facilities by appeliant to Cohn Co. and to appellee and so to constitute a violation of Section 2 (d) of the Clayton Act as amended by the Robinson-Patman Act . . ." (and at page 993) "We may further add that even if subsection (e) had been invalid, we would not for that reason have reversed the judgment because as we have previously indicated, the situation could just as properly on the evidence have been treated as a violation of subsection (d) - a fact which appellant does not dispute-and this would be sufficient to permit us to affirm the judgment if there is no merit in appellant's remaining contentions hereafter to be considered." I25. P. 335, supra.

I26. Southgate Brokerage Co., Inc. v. Federal Trade Commission, I50 F. (2d) 607,

6II (C. C. A. $4^{\text {th, I945). }}$

I27. Italics are the writer's.

I28. I50 F. (2d) 988 (C. C. A. 8th, I945).

I29. I56 F. (2d) I32 (C. C. A. 2d, I946). 
and sales promotional allowances as required under the Act. In the first Arden case, the court indicated that the advertising or similar allowances granted to customers should bear a direct relationship to the actual volume of purchases by such customers from the seller during the same calendar or fiscal year or other specified period of time; that the amount of the advertising allowance should be related to purchases by use of quantity brackets fixed prior to the time the purchases were made; in addition, that the facilities provided or to be provided by the buyer should be specifically scheduled; that the provisions on which the advertising allowances were offered should be fixed and made known prior to the effective date of the allowances and prior to the time purchases were made rather than tailored on a post-factum basis to suit the situation of a preferred buyer; that while a difference in the more ample facilities of one customer as compared with those of another might justify a corresponding difference in allowances, each customer would have to be given the same actual opportunity to qualify for proportionate allowances.

In .a final sweeping warning to sellers who felt that they could not abide by the rules applicable to the determination of advertising allowances, the circuit court in Elizabeth Arden Sales Corp. v. Gus Blass Co. ${ }^{130}$ said:

"The furnishing of a service or facility which cannot be proportionalized for the benefit of competing purchasers or, in the alternative, the failure or refusal to proportionalize the terms upon which services or facilities are granted, so as to make it reasonably possible for competing purchasers to avail themselves of such services or facilities if they desire to do so, constitutes a failure to accord such services or facilities upon proportionally equal terms."

The Circuit Court of Appeals for the Second Circuit in the second Arden case adopted the conclusions of the Eighth Circuit Court in the Arden v. Gus Blass ${ }^{131}$ opinion and applying the quoted language of the court in that case specifically condemned the Arden Company for setting up conditions for receipt of special sales promotional allowances, which it knew only a small number of its purchasers could meet.

In the recent $A \& P$ case, the court laid down additional guides for the determination of proper advertising allowances. Such allowances, the court warned, must not be based merely on the purchaser's volume, but on the definite and enforceable commitment by the purchaser to carry out certain prescribed advertising activities and on

I30. I50 F. (2d) 988, 994 (C. C. A. 8th, 1945).

I3I. 156 F. (2d) I32, I33 (C. C. A. 2d, 1946). 
proof, before payment of the allowances, of the performance of such activities. Otherwise the allowances for advertising would most likely be mere subterfuges for preferential payments to the buyer.

\section{Section 2 (F)}

While Section 2 (f) of the Act prohibits the receipt of any price discrimination, whether forbidden by Section 2 (a), (d), or (e),,$^{132}$ the buyer not uncommonly will seek to escape its impact on the ground that the section makes it unlawful for the buyer only knowingly to induce or receive a discrimination. In the quantity discount contracts with $A \& P$, for example, $A \& P$ required the manufacturer to state that it was willing to make "the same agreement . . . with any other purchaser similarly situated on proportionately equal terms" and after the Third Circuit Court upheld the Federal Trade Commission's condemnation of A \& P's unlawful brokerage practices in I939, supra, the A \& $\mathrm{P}$ had its suppliers change the contract provision to read: ${ }^{133}$

"The seller warrants that the quantity discount . . does not reflect any brokerage or brokerage savings whatsoever, and is available on proportionally equal terms to all other buyers, after making due allowances for differences in the seller's cost (other than brokerage) and for the seller's right to select his customers or to change his prices in response to market conditions or to meet competitors' prices."

In the recent $\mathrm{A} \& \mathrm{P}$ decision, however, ${ }^{134}$ the court said: "I have not been greatly interested in what either defendants or suppliers said in this respect. I am essentially interested in what they did, and . . . it seems to me that, though defendants have been careful to secure from their vendors avowals of compliance with the Robinson-Patman Act, they have been far from meticulous in acceptance of preferences which, under the facts and circumstances they knew or should have known other purchasers did not receive and that they so acted as to secure preferential discounts either under that term or other terms resulting in an unfair competitive advantage."

On the other hand, the situation that obtained in the $A \& P$ case will not be generally true in some industries, particularly in the many production industries where large suppliers ordinarily keep secret the

132. Great Atlantic \& Pacific Tea Co. v. Federal Trade Comm., ro6 F. (2d) 667 (C. C. A. 3d, 1939); Oliver Bros., Inc. v. Federal Trade Commission, 102 F. (2d) 763 (C. C. A. 4th, I939).

133. United States v. New York Great A. \& P. Tea Co., 67 F. Supp. 627, 648 (E. D. Ill. 1946).

134. 67 F. Supp. 626, 649 (E. D. I1l. I946). 
prices charged to their various competitive customers and where the customers likewise regard as highly secret the prices they so obtain. In the final analysis, of course, the rule laid down by Judge Lindley would prevail in all cases, namely, if the favored purchaser knows or should know that other competitive purchasers are paying lower prices, he will be charged with knowledge that the prices granted to him may be discriminatory. ${ }^{135}$

\section{SECTION 2 (B)}

Section 2 (b) of the Act consists of two parts. The first part places the burden upon a defendant to justify his position once it has been shown that the defendant is a party to a price discrimination. This is an application of the practice of shifting the burden of proof which, in turn, is based on the principle that a defendant who relies on an exception to the prohibition of a statute must plead and prove that he comes within the exception. The act in this respect is, therefore, not novel, but is a common practice in legal procedure. ${ }^{136}$ In fact, the rule of shifting the burden of proof apparently was recognized as a rule of evidence, even under Section 2 of the Clayton Act prior to amendment. American Can Co. v. Ladoga Canning Co. ${ }^{137}$

The latter part of Section 2 (b) deals with the availability of the defense of competition where a violation of the Act is involved, and is of very considerable interest to the businessman who usually feels that he is always justified in adopting a pricing practice that places him in an equal position with competition.

First of all, it should be observed that the defense of competition has been held to. be available only where the charge against the defendant is a type of price discrimination forbidden by Section 2 (a) or where the charge is that the defendant has discriminatorily furnished services or facilities contrary to Section 2 (e). The defense of competition has been deemed not to be available where the charge involved is payment of a fictitious brokerage fee contrary to Section 2 (c) or dis-

I35. Cf., however, Section 2 (c) in this connection which reads: "It shall be unlawful for any person . . . to pay or grant, or to receive or accept anything of value. . ." (Italics ours.)

I36. Concerning this provision, Beer, Federal Trade Law and Practice (I942) states at page II5:

"Section 2 (b) does not change the substantive offense under those subdivisions, but merely places the burden of proving justification for a difference in the treatment of different customers upon respondent. Shifting the burden of such proof to the defending party is a device familiar to lawyers, and this provision of the statute is similar to the general rule of statutory construction that a proviso carves special exceptions out of a statute and he who relies on the exception must plead and prove it."

I37. 44 F. (2d) 763,768 (C. C. A. 7 th, I930). 
criminatory payment for services or facilities contrary to Section 2 (d). In Atlantic and Pacific Tea Co. v. Federal Trade Comm. the court thus stated the point: ${ }^{138}$

"The language of paragraph (b) relates to proceedings brought pursuant to the provisions of paragraphs (a) and (e) but is not applicable to proceedings instituted under paragraphs (c) or (d)."

It is seemingly incongruous, of course, as previously mentioned (page 335, supra) that competitive practices should be available as a defense under Section 2 (b) to a violation of Section 2 (e), while not available as a defense to a violation of Section 2 (d). For injury to competition need not be shown for proof by an injured party or the Federal Trade Commission of a violation either of Section 2 (e) or 2 (d) (page 334, supra) ; and Section 2 (e) has been deemed to be in the nature of an interchangeable provision with and complementary to Section 2 (d). ${ }^{139}$ The courts have not yet considered this seeming contradiction nor decided to what extent competitive practices may constitute a defense under Section 2 (b) to a violation of Section 2 (e). It may be ventured, however, that competitive practices are and logically should be a possible defense to a seller's payment for preferential services (Section 2 (d)) just as well as to the furnishing of such services (Section 2 (e)). The language of Section 2 (b) seems to be broad enough to support this conclusion when it says that the respondent may justify his practices:

"by showing that his lower price or the furnishing of services or facilities to any purchaser or purchasers was made in good faith to meet an equally low price of a competitor or the services or facilities furnished by a competitor."

For the reference to price in Section 2 (b) may properly relate to a violation of Section 2 (d) which prohibits discriminatory payment for services, a practice which certainly is in the nature of a price discrimination and has been so interpreted in connection with the prohibition against receipt of any discrimination in price under Section 2 (f)..$^{140}$

The fact that Section 2 (b) permits the use of competitive practices as a defense only with respect to violations of certain sections of the Act does not in any event, however, render Section 2 (b) unconstitutional as at first blush it was deemed to be in some quarters.

138. 106 F. (2d) 667,677 (C. C. A. 3d, I939). 1945).

139. Elizabeth Arden Sales Corp. v. Gus Blass Co., r5o F. (2d) 988 (C. C. A. 8th,

140. See p. 333, supra; Great Atlantic \& Pacific Tea Co. v. Federal Trade Comm., ro6 F. (2d) 667,677 (C. C. A. 3d, r939); Oliver Bros. v. Federal Trade Comm., I02 F. (2d) 763,767 (C. C. A. 4 th, I939). 
Even with respect to discriminations forbidden by Sections 2 (a) and 2 (e), competition is not an absolute defense. ${ }^{141}$ A price discrimination, even though indulged in by some competitors, may injure one or more other competitors who do not indulge in it. To hold a price discrimination not to be illegal under the circumstances would be to arrive at the inconsistent position of approving one illegal practice because it was indulged in so as to meet a similar illegal practice. ${ }^{142}$ However, it will be observed that if all or substantially all competitors engage in a certain practice, it ceases to be a discrimination effecting an injury to competition.

Whether competitive practices constitute a defense to a particular discrimination is, therefore, a question of fact to be resolved by the proof elicited in each case. ${ }^{143}$

Certain guides, nevertheless, are helpful in determining the availability of competitive practices as a defense to violation of Sections 2 (a) and 2 (e). Primarily, it should be borne in mind that a justification on competitive grounds of a practice otherwise violative of Section 2 (a) or 2 (e) is defensive in character. ${ }^{144}$ As already indicated, therefore, a seller cannot indulge in price discriminations on a widespread basis in violation of the Act merely on the ground that competition is doing likewise. He can give a lower price only to a customer or customers in a local area in order to meet a particular local competitive situation in that area. He cannot, for example, give one chain store buyer a discriminatory price all over the country when the seller's competitors give such price to the same buyer in only one locality. ${ }^{145}$

Likewise, therefore, if a discriminatory seller meets a specific discriminatory price of a competitor in an area where he himself sets the general price pattern, he probably will not be absolved. Neither will a seller be absolved if he carries a discrimination further than his competitors since properly he is justified only in meeting competitive prices and payments for special services, not beating them. ${ }^{146}$ By force of the same reasoning, a defendant must show that he lowered prices to meet competition, not that he adopted higher competitive prices. And, at the same time, the fact that the seller's discriminatory prices are

I4I. 80 CoNG. REC. 9418 (I936).

I42. The Supreme Court in the Staley case, cited supra note 57 , said it was:

". . the clear Congressional purpose not to sanction by Section $2(b)$ the excuse that the person charged with a violation of the law was merely adopting $a$ similarly unlazeful practice of another." (Italics ours.) (I945).

I43. Federal Trade Commission v. A. E. Staley Mfg. Co., 324 U. S. 746, 752-753

I44. Standard Brands, Inc., 29 F. T. C. I2I (I939); BeER, Federal Trade LAW AND PRACTICE (1942) II7.

I45. 80 CoNG. REC. 94 I8 (1936).

I46. Shefford Cheese Co., Inc., 25 F. T. C. I209 (I937); Befr, Frderal Trade LAW AND Practice (I942) II8. 
lower than those he might have charged on a non-discriminatory basis, is, of itself, no defense under Section 2 (b)..$^{14 \tau}$

In this connection it is helpful for the seller, however, to keep in mind as a guide that if he can show that his lower prices in a particular instance were not below the prices of his competitors, but merely met their equally low prices, he can justify his position; ${ }^{148}$ that, on the other hand, even if he sells below the prices of a competitor, his action is defensible if he can prove that his lower prices did not prevent or tend to prevent the competitor from obtaining the otherwise available business, since in such event the price-cutting seller would not come within the terms of the statute at all. ${ }^{149}$

Since resort to and reliance on competitive practices is a defensive measure as thus illustrated, it is natural that the Act requires the seller to show that he has acted in good faith in relying on competitive practices in engaging in discriminatory practices. The seller's good faith, like the matter of competitive practices itself, is a question of fact. ${ }^{150}$

Specific and detailed proof of competitive practices and the necessity of meeting them must be adduced by a seller charged with price discrimination who attempts to justify his action on the basis of his efforts in good faith to meet competition pursuant to Section 2 (b) of the Act. From the admonition of the Supreme Court, it may be concluded that the seller's representatives or other persons must be in a position to testify or produce written proof that the lower prices which the seller allegedly met were actually given to specific purchasers in particular instances by competitors of the seller. The seller must also have knowledge of the character and reliability of his representatives or the sources of information upon which he relied, and certainly cannot rely on any source of information which he suspects of being false or incorrect.

In brief, the seller's aim under the Act must be always to give equal price treatment to all his customers, large and small. This is not only sound law; in the long run, it will also be found to be sound business since competition, which is the life of trade, depends essentially on equality of economic opportunity to all. At the present stage of industrial reconversion, it is opportune to rectify business practices accordingly. ${ }^{151}$

I47. Staley v. Federal Trade Comm., cited supra note 57.

I48. Samuel H. Moss, Inc. v. Federal Trade Comm., I48 F. (2d) 378,379 (C. C. A. 2d, (1945).

I49. Section 2 (a) requires that there be probability of injury to competition or a competitor or a tendency to create a monopoly.

150. Staley v. Federal Trade Comm., cited supra note 57.

I5I. See remarks of Attorney-General Tom C. Clark in Clark, New Basing-Point Problems (I945) Harv. BUS. Rev. IIO-III. 